\title{
Three individuals
}

A new type of warfare demanded a new type of response. Amid the jagged and broken setting, the metaphorical usage of the overwhelming effect of man's new and mechanised forms of warfare on the natural landscape became common. We have seen in Chapter 7 how this, in turn, could act as a trigger on some individuals to encompass a humanistic appreciation of the wrongness of war itself.

An awareness of the conflict's malign effects seemed to reach beyond the desolation of Nature. There now occurred a perceived alteration of the steady progress of time itself, its linear structure sometimes compressed to give the effect that time had actually halted, as in Lieutenant Wyn Griffith's account of the battle of Mametz Wood. ${ }^{1}$ For some, the effects of the war seemed to turn time in upon itself, thereby unwinding the clock of human development to a darker age peopled by trench-dwelling brutes who had lost comprehension of what they were fighting over.

This 'throw-back' concept was highlighted by H.S. Innes of the 23rd Battalion (later 20th), the Middlesex Regiment. At the battle front, H.S. Innes found himself comparing the area around the dug-outs of the front line with that around the 'outer dug-outs' further back and hence less affected by the physical effects of battle. The scene he observed at the front during the bleak winter of early 1917 was, 'the abomination of desolation. From eaves such as primitive man might have occupied we looked out over a shell battered valley. ${ }^{2}$ He noted the few remaining trees on the hillside and the stench from the lower ground, and he likened the 'canyon' over which shells whirred incessantly to one from the bleakness of Arizona. By the end of the year, he wrote that the mud all around had become a normal feature of life and that, 'war without mud would not be war'.

The unnatural and blighted landscape was once again linked directly to the war's effect on a way of life and a setting that became increasingly primordial with time. The story of H.S. Innes represents an awareness of the retardation of civilised values and the idea of man being transformed to an altogether more primitive state - in addition to the concept of individuality under threat and, as Innes put it, 'the importance of each man to himself' radically reduced. 
Innes had been one of the earliest men to be called up in February 1916, though he had not been sent to France until early December of that year, after training at Shoreham camp. Like many others, at the beginning of his training he was optimistic in outlook and clear in his motives. 'Remember', he wrote to his mother in March, 'when I am forced to be away from home as I am, that it is all in order that we may all have many happy years in peace afterwards, years which we shall value the more because we shall have paid for them' ${ }^{3}$ His mother had attempted to persuade him to avoid army service and appeal against his calling-up, but Innes had noted that men were being taken from non-combatant bodies and placed in the infantry regiments and that it was impossible at that time to obtain a transfer from one regiment to another. He remarked that he had done what little he could to avoid going to France but to no avail; the Military Service Act had transformed Britain in his view to a 'conscript country', and he rationalised the situation by submitting to the forces of destiny and a desire to have some part in the overthrow of Prussianism. Crucially, he knew that many had already volunteered ('a thing I never did'), and he felt he had to undergo the ordeal of the front in order to meet others afterwards with similar levels of experience. 'When I meet people after the war who have lost sons or brothers or friends', he rationalised, 'it will be easier for me to look in their faces than it would be if I had stayed out of it.'

The rigours of army life did not appeal to him and, when presenting arms to a visiting general, he likened himself to a performing dog and wrote with some degree of rancour to his mother that, 'A soldier is a man only when off duty, onduty he is regarded as a well trained animal. ${ }^{5}$ Being a pianist himself, his main pleasure during his training were the camp concerts, though he deplored the situation whereby some of the more talented artists were forced to lower their classical standards. Most concert items were popular chorus songs, and Innes noted critically the murmurs of boredom during one of the few classical items presented, a duet from Verdi's opera Il Trovatore. After a few weeks of training, he arrived at an explanation of why a private soldier was so-called - because, according to his experience, all the thoughts, affairs and interests of an individual were of an entirely solitary nature 'and are not admitted to exist' by the army hierarchy. The more private affairs that concerned an individual, the more they would act as an encumbrance. 'The army is no place for a man of intelligence', Innes wrote, 'or one who is used to active independence, whether in business or in his spare time.' 6

The burden of his experience pressed Innes to greater depths of criticism of his new, regimented life and the anomalies he found therein, such as the wastes of labour and instruction apparent when he observed qualified farriers or signallers being sent abroad as ordinary privates as well as the decisions of one day being reversed the next for no apparent reason. All this left Innes with little confidence in his future and the daily practicalities of life. He could only place his faith in abstracts and thus attached his uncertain fate to that of 'the nation', 
in whose future he felt more confident ('The duty of the nation is the duty of the individual'). This reasoning relieved the pressure of conscience to such an extent that he now found himself able to examine the inequality of service that he saw existed around him, such as those individuals who had innocently obtained jobs before the war only to find these posts assuming irrational importance in time of war and hence were able to serve their country with honour without having to actually engage in any form of combat, while others were protected from the firing line by specially selected 'safe' military positions hastened into at the outbreak of hostilities.

Innes also highlighted the general hostility that he found existed in the army towards secure civil occupations with long hours, high pay and security. In addition, he noted that during the confusion of the early days of the war some of a timid nature had been able to 'make havens for themselves' while others, bound up in a mood of reckless patriotism, 'went out early and died long before the country knew what it was they were suffering, or what they were fighting against'. Now, in late 1916 and after conscription, Innes deplored the fact that so many individuals with careers and responsibilities before them had been obliged to set their lives to one side to make way for the demands of the war. $\mathrm{He}$ concluded, 'The importance of each man to the country has increased, and consequently the importance of each man to himself has decreased'.

Patriotism had to consist of deeds as well as words: in other words, positive action of some kind. Innes saw this but felt that there should be no glory attached to the individual's choice of action which in any case had been stifled to a certain extent by the constraints of a wartime society and, most especially, in the army where individuals were generally treated like animals, according to Innes' observances. Suitably, in his own case, once Innes reached France (feeling himself 'unfit for battlefield by physique or temperament') he was set to work constructing dug-outs amid clouds of chalk dust. Despite his support for positive action of some kind, Innes found his mind turning in other directions. 'I long to be somewhere where the decent side of life is to be seen', he wrote to his mother 'Perhaps my ambitions will revive after the war - but at present all I want is a quiet life on a moderate income and a bicycle in an English countryside and you to look after (I should have put you first)'. ${ }^{8}$

In March 1917 he realised that it would soon be Easter ('I have sufficiently regained a sense of time') and mused upon the Resurrection which he could not help evaluating in terms of his present existence. He found himself wishing for, 'the resurrection of this life', for, as he had found, 'this existence is death, mental and usually spiritual'. 9 At the end of May, Innes was summoned back to base in order to appear before a medical board, and he hoped to be marked down for permanent base duty. At the base, while awaiting his result and watching troops passing in and out, with some bound for the front, he expressed unease at the vagaries of existence and the lack of certainty in things, with men heading towards different fates: an anonymous death or the VC, depending 
upon war's caprice. He found himself struck by the 'the element of dreadfulness' in this intersecting of artificial existences.

Although he was assigned to permanent base duty and became a Field Cashier at the headquarters of the XIV Corps of the BEF, he still found himself unhappy and unfulfilled, despite varying his 'programme' by walking in the nearby woods on fine evenings and occasionally playing the organ at Sunday evening services. 'Things worth living for are rare in the army: duty and preparation for duty ... occupy one's entire existence, ${ }^{10}$ he wrote in the summer of 1917 , during which time he noted how easy it was to become indifferent to the war when one was behind the lines for a length of time. However, he admitted, any element of the old uncertainty (and even the bleakness of trees rustling dismally in a gale) 'brings back its [the war's emotional impact] hard side' immediately.

In September 1917, Innes was granted leave and transferred from the Middlesex Regiment to the 273rd Employment Company of Field Cashiers. Back in London, he found that his 'conscript country' had become worse, to the extent that, as he noted, the practice of saluting when on leave had been forcibly revived:

so that apparently harassed and war-worn men are in theory obliged to stand to attention in overcrowded Tube carriages (if they are not doing so at the time) whenever an officer enters, or the latter's hand on its way to seek support from the nearest strap must not omit to pause distinctly, if briefly, in the region of his hat-peak. ${ }^{11}$

By the end of the year, he found himself sent to Italy and established in a draper's shop which acted as his billet and office. By mid-1918 he had only received fifteen days off in the previous eleven months, despite working for nine hours every day, seven days a week. He became 'stale' and realised that he could never be content until the war was over 'and everybody has a fair chance again'.

Ironically, Innes would suffer delayed demobilisation and not return to his former life until September 1919, becoming increasingly frustrated with a life that he had never been in tune with, even during the urgency of war. 'With constant thought for the morrow and constant devising of ways and means', he had written during the uncertain period of the last great German advance of spring 1918:

life ceases to be life and becomes existence. When one's desires and inclinations are cramped and thwarted on all sides, monotony, if not slavery, results ... the whole world is in a fever with this war disease and things cannot go on in the usual way ... we still measure life by the old standards, while the fact is that the better comparison is not with what we have known but with what we shall have to face. War upsets the routine of civilisation; the world goes backwards instead of forwards. ${ }^{12}$

In his explicit recognition of the conflict's upset of civilisation's calming and steady progression and all that implied about the state of mankind and hope for the future, the experience of H.S. Innes reflects in greater detail the concerns 
and feelings of other similarly-minded individuals, many of whom have already been discussed elsewhere in this book.

Occasionally an individual can be identified in whom many of the various humanistic objections to the war and the minutiae of the conflict (embodied to greater or lesser extents in the individuals previously considered) existed side by side - though not in isolation. Indeed, they seemed to coalesce and create a personality which, to some extent, was a result of the abrasion between a humanistic approach to life and a sense of duty which assumed forced contact with circumstances of death and destruction. Frederic Hillersdon Keeling is not remembered to any great extent as one of the major figures of the war, but after his death on 18 August 1916, he was mourned by those that had known him as a perfect example of the 'gentleman-soldier' and as 'one of the most remarkable men in the army', according to the captain of his regiment - a regiment in which he had become something of an institution by the time of his death.

Keeling mixed in various circles and recognised from personal experience (in common with Bertrand Russell) that there was little common ground between the 'demagogic Socialists' and the 'Hypersensitive aesthetic intellectuals'. He knew Rupert Brooke and, like him, had started to drill with the Artists' Rifles in August 1914 though, unlike Brooke, Keeling refused a commission, deciding instead to enlist in the 6th Battalion, the Duke of York's Light Infantry as a private because he wanted to have a wider knowledge of experience of the war. Joining up, he felt, was, 'not dishonourable in itself and gives one direct experience of another side of life and another way of living altogether'. ${ }^{13}$ By this action he also felt that he had more in common with the ordinary soldier. This decision was nothing out of the ordinary for Keeling, a man who, despite his First from Cambridge, had chosen to manage the Leeds Labour Exchange in 1910, when he was only twenty-three.

When war was declared, Keeling felt a sense of duty and a desire to be part of the coming experience though he appreciated that his feelings did not involve any 'war cult' and that the individual did not have to share in the national and racial tension that engulfed the country ('a miserable vicarious emotion'). It was enough to recognise that this feeling existed and to perhaps be wary of it, while deploring the lack of sense exhibited by all nations and English insularity in particular. He had just visited Germany and found himself feeling a kind of 'secondary patriotism' for that nation and found himself more suspicious of Russia than he was of any Teutonic threat. He found himself greatly disturbed by the 'damnably mean' treatment meted out to German shops, governesses and servants by the British press and people. If there had to be war, it must be fought without passion or bitterness but with respect for the 'enemy'; he wanted Great Britain to triumph on the sea and Germany on land and then both to keep the peace thereafter. This was Keeling emoting, as he inferred, on a practical level, as a 'political animal'. On a deeper level he expressed more passion; 'As a man', he wrote on 2 August, 'I detest the conception of one national culture regarding itself as essentially the enemy of another'. ${ }^{14}$ 
He also thought of the situation in moral terms, wishing that any moral results of the conflict, such as those of comradeship and brotherly love, would outweigh the inevitable material losses, and he found himself frustrated by what he saw as a lack of perception of these potential material losses by the general populace; the holidaying people he observed at Cowes and in the train did not seem to him to see that they were all on the brink of the 'greatest abyss in history'. Amidst the whirl of patriotic headlines, speeches and calls to arms he wrote sadly from the National Liberal Club at midnight on Monday 3 August that, 'There is no room for one's personal feelings now ... It is too awful for words. ${ }^{15}$

The German destruction of the medieval city of Louvain did not move him as much as he expected it to, due partly to the fact that during the first few weeks of the war, as he commented, 'The everyday life of the present is my main interest', and he found Louvain and its history to be rooted too deeply in the past, although he imagined that if he were to be ordered to destroy a beautiful town he would probably be horrified - however on reflection, he speculated, 'perhaps it wouldn't if one had been engaged in fighting for weeks on end', which indicated his recognition of a coarsening of sensibility that went hand in hand with military action. He was determined to avoid all cant and false emotion: 'I am not going into this job in a simple swelling mood of patriotism', he wrote, 'That is there, but there are a lot of other things, personal and impersonal, which complicate it. ${ }^{16}$ Although he admitted that the destruction of Louvain by his beloved Germans was a 'blunder', he found it impossible to work up any feelings of animosity towards them, and he realised that 'We're all capable of pretty bad things given the least encouragement to barbarities; it is absurd to blame the men. ${ }^{17}$

Keeling's main concern was that civilisation, as he saw it, was slipping backwards, and there was no guarantee at this early stage in the war that the world would emerge any saner at the end of the conflict. He worried that his own countrymen would be encouraged by politicians and pressed to learn to hate the Germans over time, a mood which would obscure that of international brotherhood that he believed in so keenly. 'I expect I shall be a stronger pacifist after the war than any of the people who are pacifists now', he wrote, adding crucially, 'But I don't feel one will have earned the right to be one unless one has gone in with the rest. ${ }^{18}$ The war was to be a test of the strength of his personal anti-war feeling.

Once in the army and kept busy training, Keeling found himself as he had feared, suffering a blunting of his sensibilities and was shocked to find out how easy it was, now that the army staked a claim to his soul as well as his body, to become immune to the beauty of a sunset or early morning mists. Only occasionally did he find that these sights brought back a 'grubbing in one's wretched soul'. Most of the time he felt isolated and devoid of feelings; now, his 'most real life' was with his own inner thoughts, and this encouraged him to the 
resolution (as it had Siegfried Sassoon) that, 'one must keep an inner life going', if one wished to preserve anything of an individual's former independence of thought if not of action. His feeling of comradeship was one of the few positive features he identified from the circumstances of army life and the wider conflict ('What a brotherhood there will be between all those who shared the experience!'). He could not believe that the ordinary soldier harboured feelings of intense hatred towards the Germans and was sure that these feelings were the product of 'ranters and intriguers'; journalists, pro-war intellectuals, politicians and the highest ranks of the army.

There was also the excitement of the unknown, the thrill of 'the greatest game' (as he referred to his progress towards the front) which existed whatever the moral or immoral results of the war. Keeling felt that the process of facing up to the imminence of death could lend one a more realistic sense of values in life, especially that of liberty, or the lack of it, and he was quick to praise voices of perception and calm common sense, such as George Bernard Shaw's 'Common Sense About the War'in the New Statesman which he described as 'magnificently sane'. Besides the simple attraction of certain excitement, however, there was a deeper need to be part of things in some that Keeling saw as a psychological necessity: 'I don't think an average man can be sure of being sane about this business unless he knows he is going to face death like the rest', he wrote from Witley Camp in April 1915. ${ }^{19}$

It was at this point that Keeling finished his training and embarked for France, possibly suspecting (from the stories of those who had returned) that what he had already undergone was as nothing compared to the horrors ahead. He was now somewhat used to the routine of the army, especially expressed by the calls of the bugle ('They have eaten into my soul') though he was still depressed by the spirit of hatred that abounded and was forced to place his hope in some kind of international outburst against the war which all soldiers who had experienced the front would respond to. Once on the continent he found that, on his time off, he had more opportunity than before to appreciate the beauty of the scenery although this was contrasted with the 'rough standard of physical civilisation' to which he had sunk when forced to endure sleeping rough, lice and the 'obnoxious' inequality of the army's standards between officers and common soldiers.

More seriously, he found that his relationship to all things, both external and internal, was, 'under the shadow of the big gun'. He continued, 'One lives enjoys life full-bloodedly and even thinks and feels aesthetically now and again - but having come away, one knows that there was a special abnormal tinge over the whole of life. ${ }^{20} \mathrm{He}$ saw that the limit of experience of the infantryman in this war was greater than ever before and hoped that, in response, there would be a correspondingly large wave of practical pacifism after the war in which he determined he would play a part by going to Germany and re-establishing ties with German life as well as creating new ones where possible. 'It is 
the soldiers who will be the good Pacifists - just as every decent Pacifist should be a soldier', he wrote to a friend. ${ }^{21}$

It was his direct experience as a soldier that compelled Keeling to write a powerful article for the New Statesman against the issue of compulsion. 'Now that I know what one's experiences in the firing-line at their worst actually are', he wrote, 'I cannot as a responsible citizen of a democratic community be a party to compelling any man willy-nilly to share them'. He stated that he was not concerned with the logical end-result of this point of view in terms of the state's relation to the individual, only that no man should be forced against his will to experience the 'hell' that he had undergone, concluding that, 'I feel a moral objection to compulsory service which I never felt before I had come to France as a soldier. ${ }^{22}$

Despite his anger, hope and convictions, Keeling was becoming tired of the 'mud, monotony and murderousness' of his circumstances by late 1915 . The constant edge of death had transformed the experience from artificial adventure to actuality with no opportunity in the spring of 1916 to enjoy that which he most craved - time to enjoy the beauties of nature in peace, away from the guns. 'Every pleasant landscape now seems to suggest the horrors of war by contrast', he wrote wearily in March. Even the sound of the larks at dawn now only brought him unhappiness through their reminder of peaceful gardens of former days: 'Here one knows that the larks sing at seven and the guns begin at nine or ten.'

Frederic Keeling was killed later that year, in August 1916 - caught by a bullet as he stood on a parapet. His Captain, Barrington-Ward, recalled Keeling's disciplinarianism, his energy and most of all, his kindness (and bad language) towards his men. 'We shall be hard put to re-arrange ourselves without him', he commented. No less a figure than H.G. Wells provided the Introduction to a volume of Keeling's letters which appeared in 1918 and wrote in stark tones that, 'Keeling's life was a full and vivid one, but it was largely wasted ... What a fund of vitality, what a power of work, what a promise of youth, fell back into darkness with this one life! ${ }^{23}$ Wells saluted Keeling's supreme individuality, best expressed by Keeling himself who, having no use for religion ('it seems no good in this hell'), misdirected hatred and the false rhetoric of politics and press, affirmed that, 'speaking as a man face to face with the chances of death, I can honestly say that humanity and England's contribution to the Temple of Humanity are the only ideal conceptions for which I have any use'. ${ }^{24}$

If Frederic Keeling represented a standpoint on the war that was charged with feelings of both duty and repulsion, with pity and concern for humanity emerging as paramount concerns, then that of D.H. Calcutt of the Queen's Westminster Rifles was of a less emotionally complicated nature, based on much more practical objections. Calcutt, a civil servant with the Home Office since 1910, possibly suspecting that conscription was inevitable and close, applied on impulse and was accepted by the armed forces in late 1915 - much to his 
surprise (and that of his employers), as he had expected to be rejected on medical grounds, as he had been by the Home Office on the occasion of his first (pre-war) job application. In August 1914 Calcutt had been entrusted with the task of informing all 222 Chief Constables of the British Police Force of the outbreak of hostilities between Britain and Germany, and Calcutt's wry, fussy, objective tone is initially evident when he noted that the telegrams he sent read that Germany had declared war on Britain when, in fact, the situation had been the reverse, lending, as he saw it, credence to the adage that the first casualty in war is truth.

Right from the start of his military career, Calcutt harboured feelings of resentment and unease, feeling himself to be something of a coward and disliking being forced to associate with others of poor physical condition, 'from all points of the compass'. Like H.S. Innes, he was frustrated by the elevation to hight rank of those 'with apparently no higher mental delights than are to be found in seeing a lot of men making a single inane movement simultaneously'. ${ }^{25}$ More seriously and in common with others such as E.P. Southall and Guy Chapman, Calcutt was worried by the general lowering of moral standards that he felt was produced by the war. An aspect of this was to be found in the conduct of the authorities in coercing the manhood of Great Britain to join the colours. As Calcutt saw it, this involved a gradual breaking down of the resistance of small categories based on marital status, occupation, age, etc., leaving the remainder either full of false hope of being spared the front or placed forcibly and publicly in a morally dubious position. According to Calcutt, the remaining adult male population of late 1915 had been 'prized out of their niches individually' by an unfair sleight only to be shunted around like so many milk churns, once in the army, sometimes left in a siding for hours at a time. He described the common soldier as being like a horse in a horse box gazing backwards rather vacantly with blinkered vision, never able to discern the true direction of the road ahead.

After some training, all the less physically fit soldiers were transferred to the Rifle Brigade Garrison Battalion at Falmouth and in December 1916, after a year in the army, Calcutt was shipped with his regiment to Egypt. He described the crowded conditions on the Mail Packet Connaught as a sea of khaki - 'ugly, utilitarian clad bundles of humanity' with their meagre possessions scattered about them. The boat was torpedoed in the Mediterranean and at the church service following the incident Calcutt noted the tendency towards deeper religious feelings when threatened by acute danger. He also observed that the army Padre had 'easy stuff' to work on with a collection of scared men and boys many miles from familiar surroundings. All that had to be mentioned for them to 'ooze religion' were the usual homilies such as 'friends at home', 'old folk' and 'wounded and distressed'. However, Calcutt also observed how soon this pious atmosphere could be shattered by a command to 'fall in' for the march back from church to camp. 'Oh - if only we had the courage of our thoughts and inclination', Calcutt recorded in his diary: 
We are not afraid to die, we are afraid to live. The Church merely tries to bridge the gulf between reason and practise by 'His will' and talk and prayer. Send high explosives over and then pray for the recovery of the wounded. Love them that despitefully use you. Oh! What a coward I am. ${ }^{26}$

His self-denunciation was for his lack of courage in his own convictions: for not refusing to take part in the service. As it transpired, the following week church parade was declared voluntary due to lack of interest. Calcutt's bitterness here was also a (perhaps unrecognised) self-taunt for not possessing the ability or will to publicly proclaim his views on the army and the conduct of the war itself.

Calcutt's stance was fed by his general attitude towards religion, which he thought of as a cloak put upon a man at birth and worn forcibly for the remainder of his life. In Calcutt's view, it was unfair to clothe a man externally in a particular point of view with no respect for any independent internal outlook. Religion was an action performed on a man not unlike vaccination and for it to be effective it had to spring naturally from inside, though, 'the man who thinks at all, as often as not, finds it does not suit him' ${ }^{27} \mathrm{He}$ contrasted the powerful position of the Church in the Middle Ages and at the start of the twentieth century during wartime and found them to be oddly similar, describing the modern ecclesiastical stance during war as, 'selling buns to conscript serfs at places where buns are not otherwise available'.

By the spring of 1917, Calcutt was stationed at Kantara in Egypt, and it was at this point that he found himself in contact with some of the more direct effects of the war. At the 24th Stationary Hospital some of the worst cases made him feel 'more anti-war than ever', and he worried on behalf of the wounded that the frequent grumbling of the stretcher-bearers would only serve to remind the casualties that they themselves were still in the army. He still retained his eye for the odd or slightly ludicrous; one example was his newly arrived substitute, a small, deferential old man in an ill fitting drill tunic, baggy trousers and rumpled puttees whom Calcutt likened to a bird, especially since the man's broken spectacles hung from one arm on a piece of string and were continually being held up to his left eye and peered through. Calcutt thought him a figure of mirth until the man spoke of his son of twenty-one, killed in France. Calcutt saw this personal loss and the man's subsequent loss of dignity as a whole and representative of the material tragedy of the war, especially when he learnt that the man was fifty-seven and had claimed to be thirty-eight in order to enlist.

Calcutt remained angry with himself for failing to take some kind of personal stand; in a letter from Kantara he wrote that he wished he had declared himself a Conscientious Objector from the beginning. 'I have sold my soul to the Directors of British Interests for $£ 45$ a year', he lamented, 'I am in a whirl of circumstances, like the rest of us, but I clearly see the circumstances and instead of proclaiming it ... I allow myself to drift along as fate and the medical boards 
decree. We are not free, we do not follow our own inclinations for a moment. ${ }^{28}$ He found it easy to be cynical; church parades were a travesty, the addresses of Brigadier and Commanding Officer 'hesitating and unconvincing' and full of 'fulsome rubbish' respectively. Divisional concerts were the army's method of ordering the men to be 'cheerful by numbers' and a soldier's personal discretion was continually interfered with 'right down to a strap and a buckle'. He was well aware that for many his objections were not an issue, but he felt forced to uphold the moral and aesthetic standards of himself and others for, "honour and susceptibilities, like taste and appreciation of art, are subtle things' and an order could easily transcend the realm of self-respect and degenerate to the level of self-humiliation. He privately berated others for being too thick-skinned to be aware of these regular intrusions.

Calcutt's chief consolations were his extensive reading (his book list for September 1917 included Jane Austen, Byron, Wordsworth, Browning, Matthew Arnold and Marcus Aurelius) and his stretcher-bearing, which he regarded as action directed at saving life rather than destroying it. He appreciated most forms of natural life in the desert and possessed an almost child-like interest in small creatures, especially the lizards (though not a six-inch spider attracted by his evening candle; 'I screamed'). He found depressing the lack of greenery or feature in the barren landscape ('not unlike the downs around Winchester but unrelieved dust colour'), and he was especially plagued by the constant flies. By the end of 1917, Calcutt was exhausted after many marches in wind and rain, disturbed sleep under wet blankets and worsening sciatica, though he tried to make light of the physical hardships and recognised that his mental state was more fragile. Physical hardship could be linked to obvious cause (though not reason) whereas on a mental plane he found himself plagued by 'some irritation I could not see the reason for'.

Calcutt found himself constantly frustrated by the random illogicality of military activities. He cited the occasion when his company spent two days marching away from Jerusalem at the end of December in appalling conditions only to be told they would be returning there forthwith. There was also the time in February 1918 when, in pouring rain, they dug trenches and were ordered to scatter the resulting earth around the camp, turning the whole place into a sea of mud. Then they received orders to collect all the dirt again and make a 'trench pile' on one side. Finally, the notorious Captain Flower ('dry as a bone') ordered the trenches to be filled in again as they were crooked. This, combined with episodes of arduous road-making in freezing conditions, brought Calcutt to the edge of despair, especially since he had been largely unable to make friends in the army and now admitted in his journal to a feeling of 'absolute loneliness in a crowd' coupled with the 'maddening' frustration of the pettiness of military life. He described himself at this time as being, 'Mentally, morally and physically SICK and FED UP' amid the 'usual atmosphere of RUSH and MADDENING INSPECTIONS and ETERNAL FAULT FINDINGS.' 
Calcutt sensed that he was being drained of any remaining personality by the impersonal nature of the army's treatment of the individual, especially when he was referred to simply as 'the man who dropped his rifle' by the sergeantmajor. As he noted, 'The expression of one's own personality is life, and the cramped, limited, dog's life under military discipline is not worth living at all. ${ }^{29}$ He regretted the filtering away, as he saw it, of natural emotions such as true courage and honour. The courage that he observed after a day's drilling on the parade ground was merely 'the courage of discipline' and, as he later recorded, 'all restraining senses of decency vanish under discipline'. ${ }^{30}$

In June 1918, Calcutt embarked on the Indarra for Southern Italy. His physical condition was now so bad that he was admitted to the 79th General Hospital at Taranto with a temperature of $102^{\circ} \mathrm{F}$. After his recovery, he was transported by train through Italy and into France. ${ }^{31}$ In the autumn of 1918, the Division started to take 'civilian life' courses. Calcutt chose shorthand, journalism and French, hoping grimly that he lived to make use of them. He was also granted leave unexpectedly and returned home to find his mother out, which gave him time to hide his 'horribles' (rifle, gas helmet etc.) in the larder before she returned. Despite his attempt to settle back into the comforting gossip of home life ('Cathie is married and Em'ly jilted ... Cecil well in tow'), he could not forget the war and found himself walking restlessly around Kensington Gardens and Hyde Park as his leave dwindled away. A visit to the theatre in Drury Lane was spoilt by an inebriated Major who was sick over a girl's dress in front of Calcutt and his party. This incident seemed representative of the false gaiety and intoxicated emotions which only partially concealed the war-weariness of the conflict's closing months.

It was a weariness that, in Calcutt's case, had tinted his view of events for many months, and the approach of the end of the war brought no lessening. The landscape of France he saw when travelling by rail to the Divisional HQ after his leave was 'the most awful picture of destruction I have ever clapped eyes on. Derelict tanks, rain sodden, shell torn, trench cut country, railway lines and concrete all over the place. Miles and miles of this ... ${ }^{32}$ To him it seemed as if the landscape was as worn out and shattered as those experiencing the war. He encountered a German placard, aimed at the Belgians, depicting the English dropping bombs on German hospital trains, and Calcutt saw this as a symbol of the mutual messages of hate and lies which were hurled around between the belligerents, the only result of which was 'misunderstanding beyond reconciliation', and the suffering of innocents. He came across a battered village on the banks of the Scheldt river only a week before the Armistice and mused that a fortnight previously it had been relatively peaceful and now, though it had been 'recovered' or 'freed', this had meant its virtual destruction. All that was left was, 'a painful reminder of human suffering'.

It was the suffering of the man in the field and the innocent civilian that Calcutt could not forget once peace was declared. The date 11 November was 
marked by squad drill, instruction in the manipulation of the Lewis gun and little else; 'we have not facilities for rejoicing ... Henley's brother is dying. Corporal Jacob's brother has just died. Newson's brother killed last week. A few Very lights are fired but very weak as a daylight demonstration .... ${ }^{33}$ To Calcutt, there seemed no 'victory' to celebrate, and the highlight of his day was a game of pontoon before turning in. A speech given by a General at the end of the month confirmed Calcutt's identification of the gulf that existed between a Divisional General and 'the poor clod in the line', a gulf across which real understanding of the latter's 'daily humiliation' was impossible. The General's remark that the troops had never looked better and would not be recognised when they returned home provoked an outburst of indignation from Calcutt. 'What of the dead? Poor Sergeant Sheperd rotting on the top of a desolate mountain-top in Palestine looks well doesn't he? And Pat Brady and Calvery and Geeson. Are we to forget them all so soon ...' As the General entreated the men to remain in the army in the period following the war, Calcutt likened the insensitive, business-as-usual attitude to Prussian militarism. Reviews, parades and pageants could only result in 'the dead and mutilated at the bottom of a mud-soaked trench'.

He did not return to England until June 1919, when he was granted a month's leave prior to demobilisation. Despite Calcutt's emotional turbulence and physical illness, he had carried on and tried - like so many others - to make the best of it, perhaps realising that he was undergoing a defining experience. He stopped his diary on his return home, and his last entry described a visit to the theatre to see a play about Napoleon at which the audience, still affected by 'war-fever' to some degree, applauded the deriding of the Austrian national anthem by a French chauvinist when, to Calcutt, it was obvious that, at the time of the Napoleonic Wars, France stood for militarism. 'Still', wrote Calcutt characteristically, 'it showed constancy anyway. After that we went home by bus and told each other when we got home that we had enjoyed ourselves. So I suppose we had. ${ }^{34}$

The war had wrenched Calcutt from an ordered, if slightly insular, life and constantly underlined his sense of being out of place and involved in something against his nature. His facility for critical observation, which privately balanced his public shyness, was forced to the fore by the events he was compelled to undergo or witness, but this was not to the detriment of his real kindness and sympathy for those he regarded as trod upon or exploited. He was painfully aware of the war and its stripping away of all façade and pretence to the essentials of life, however petty. 'What a prosaic, unromantic war this is', he wrote, 'All the little refinements and secret sensitiveness are torn aside and love finds expression in a cake of soap'. ${ }^{35}$

Within the personal stories of H.S. Innes, F.H. Keeling and D.H. Calcutt, there lie buried familiar shards of aesthetic, humanistic and moral opposition to the war. Innes' awareness of the 'abomination of desolation' at the front mirrored the bleakness of the 'conscript country' that he felt Britain had become. 
In Innes' opinion, conscription and the war's general demand for men had allowed the importance of each man to himself to decrease. Individual personality was becoming submerged and life itself, as a consequence, was being reduced to the level of 'mere existence'.

Keeling's recognition of the 'abnormal tinge' created by the war enveloped his 'inner life', leaving, as he saw it, no room for personal thoughts and feelings. Added to this was the parallel reaction of his identification with the life of the soldier as a means to 'earning the right' to pacifism through channels of 'direct experience', and his hope that this brotherhood of experience would result in a shared understanding of the horror of war and thus a reduction of future international conflict. This recognition of the importance of experience to a full appreciation of the meaning of the war is a theme already observed in this study, particularly in the cases of Sassoon and of Owen in Chapter 5, who resolved not to be satisfied until he had 'suffered my share of life'.

Just as Keeling expressed a moral objection to the introduction of compulsion, Calcutt deplored the general lowering of former standards of morality by which he had fixed his life and values. At the same time, he came to see what the war ultimately meant to him, a realisation facilitated by the acute observances of his reluctant participation within it. Calcutt was keen to view himself as upholder of moral and aesthetic standards on behalf of not only himself, but also of others. He was aware that standards of personal honour and sensibility could easily be transgressed by both the horror of the front and the artificiality of the structure of military life. Self-respect was continually at risk, and this intrusion into standards of individual morality was what caused the greatest torment to the sensitive Calcutt and others like him. For all three soldiers the war had upset, in Innes' words, 'the routine of civilisation' - not only in the wider sense of their awareness of altered standards of public morality, but also in the conflict's warping of their personal hopes, dreams and aspirations. Thus the war divorced them from their own lives.

\section{Notes}

1 'Past and future were equidistant and unattainable.' Wyn Griffith, Up to Mametz (London, 1931), p. 212.

2 University of Leeds, Liddle Collection (UL,LC hereafter), file of H.S. Innes, letter to his mother, 5 Jan. 1917.

3 Ibid., H.S. Innes to his mother, 6 March 1916.

4 Ibid., 9 May 1916.

5 Ibid., 26 April 1916.

6 Ibid., 13 July 1916.

7 Ibid., 30 Oct. 1916.

8 Ibid., 9 March 1917 and 23 March 1917.

9 Ibid., 24 March 1917.

10 Ibid., 3 July 1917.

11 Ibid., 20 Sept. 1917. 
12 Ibid., 1 May 1918. For details of a similar reaction to that of H.S. Innes, see file of R.M. Gale (also UL,LC), a Royal Marine in the Divisional Engineers of the Royal Naval Division. The former Post Office telegraphist describes the 'soul-destroying slavery' of military life and how he feels that it, 'drives iron into a man's soul'. (See Diary 3, 26 June 1917 and 15 Jan. 1918).

13 Keeling-Letters and Recollections, ed. E.T. (London, 1918), p. 185.

14 Ibid., 2 Aug. 1914, pp. 178-9.

15 Ibid., p. 180.

16 Ibid., Aug. 1914, p. 187.

17 Ibid., Aug. 1914, p. 187.

18 Ibid., Aug. 1914, p. 187.

19 Ibid., April 1915, p. 202.

20 Ibid., to J.C. Squire, BEF, 7 Aug. 1915.

21 Ibid., to R.K.C. Ensor, 23 Dec. 1915, p. 259.

22 F.H. Keeling [writing as 'A Sergeant in a Line Regiment in Flanders'], 'A Soldier on Compulsion', New Statesman, vol. 5, no. 130, 2 Oct. 1915.

23 H.G. Wells, Introduction to Keeling -Letters and Recollections, ed. E.T., p. xiv.

24 Ibid., p. 264.

25 Imperial War Museum, file of D.H. Calcutt, transcribed diaries, Introduction - 'Beneath the Veneer', p. 1.

26 Ibid., vol. 1, 2 Sept. 1917, p. 97.

27 Ibid., vol. 1, Memo (no date), p. 103. Calcutt was particularly unimpressed with the Padre of his own Regiment, a character who conversed continually in 'timid parables'. The nonconformist Parson met with equal lack of enthusiasm, not only from Calcutt, but from most of the other soldiers as well. Calcutt described a church parade over which the parson presided as being a 'chronic wash-out'; the chosen sermon - that of the Good Samaritan - did not reflect the war nor the relationship between the Church and Army, while silence greeted both the hymns and even 'God Save the King'.

28 Ibid., vol. 1, letter to Pat, 31 July 1917, p. 90.

29 Ibid., vol. 2, 27 Feb. 1918, p. 21.

30 Ibid., vol. 2, 15 May 1918, p. 52. The general misery, bewilderment and loss of direction that Calcutt experienced was amply demonstrated by an incident on the Nabour Road in the spring of 1918. Calcutt and his company had been marching north and, in order to reunite with the main battalion, they had left the road to climb over higher ground, in what was presumed to be a short cut. After hours of clambering around in the hot sun without a 'long halt', it was decided to find a road again and look for the Battalion. It was 3 o'clock in the afternoon by this point, and the men had had nothing to eat since sunrise. After scrambling down a hill, a road was found and followed until it was realised that the company was now marching south - and in the opposite direction - on the very road it had left that morning. In order to reunite with the Battalion, Calcutt and the men had to completely retrace their steps, including returning to the far side of the hill they had just scrambled down and partially skirted. Almost inevitably, they found that the Battalion had completed the job in three hours, including three halts.

Calcutt recorded this incident with a tone of self-satisfaction, as if this proved, once and for all, that his pessimism was entirely justified. He still felt isolated and stifled; he was 'reduced' to reading Mrs Mason Protests by Anthony Hope and the acquaintances he had built up he labelled 'Friends of Convenience'. Nothing could be real or resemble the friendships of the old life in a situation precarious with uncertainty and fairweather values. 'We do not live', he wrote in May 1918, 'We are in a whirl. Not a minute to yourself. One thing after another. We just exist.' Ibid., vol. 2, 28 May 1918, p. 57.

31 Calcutt found himself passing through numerous towns and cities ('St. This and St. That') seemingly untouched by the war, such as Cannes and Marseilles. His spirits improved slightly 
when he observed the beautiful wooded scenery along the banks of the Seine as he travelled northwards. However, the pleasure evaporated when he noticed the lumbering being carried out for war purposes - the extra lines being added to the railway and the construction of more embankments and bridges.

Just as the altering scenery was speeding past his train window, so life at home was passing him by, affording him only glimpses of altered circumstances. He received a letter from his niece Eileen, who had started school. 'I had no idea she was so old', he wrote with astonishment. Once at the Western Front, Calcutt went into a shell-torn house to have a look around and found that he could not help but view it as the home it once had been, particularly since a Singer sewing machine and numerous Virgin Marys were in evidence, as well as family photographs, in cracked frames, still on some of the walls. It was these 'intimate threads of life ... ruthlessly broken off' that he felt brought forth the true tragedy of the war to a greater extent than even the remaining gaunt trees of France, 'stretching their stricken forms upwards, silhouetted every instant by shell flash and Very light'. Ibid., vol. 2, Sept. 1918, pp. 96-8.

32 Ibid., vol. 2, 26 Oct. 1918, p. 121.

33 Ibid., vol. 2, 11 Nov. 1918, p. 128.

34 Ibid., vol. 2, 24 June 1919, p. 65.

35 Ibid., vol. 1, 18 July 1917, p. 85. 